\title{
$5-2014$
}

\section{Persistence of ex-ante volatility and the cross-section of stock returns}

Prodosh Simlai

University of North Dakota, prodosh.simlai@und.edu

How does access to this work benefit you? Let us know!

Follow this and additional works at: https://commons.und.edu/ef-fac

Part of the Economics Commons

\section{Recommended Citation}

Prodosh Simlai. "Persistence of ex-ante volatility and the cross-section of stock returns" (2014). Economics \& Finance Faculty Publications. 8.

https://commons.und.edu/ef-fac/8

This Article is brought to you for free and open access by the Department of Economics \& Finance at UND Scholarly Commons. It has been accepted for inclusion in Economics \& Finance Faculty Publications by an authorized administrator of UND Scholarly Commons. For more information, please contact und.commons@library.und.edu. 


\title{
Persistence of ex-ante volatility and the cross-section of stock returns
}

\author{
Prodosh Simlai ${ }^{1}$
}

\begin{abstract}
We suggest a new measure of total ex-ante volatility $(E A V)$ in stock returns, which includes traditional non-market (or idiosyncratic) risk and the unexpected component of market return. We find that the portfolio-level $E A V$ measure exhibits strong predictive power for the cross-section of average returns during the post-1963 period. We demonstrate that (1) the persistence of $E A V$ gives rise to economically significant spread in returns between value and growth stocks, and (2) the cross-sectional dispersion in stock returns is positively related to the estimated value of $E A V$. The benefit of the $E A V$ measure is that it is countercyclical and contains relevant information about the time-variation in value premium.
\end{abstract}

Keywords: value premium; ex-ante volatility; bivariate EGARCH model; cross-sectional returns JEL Classification: G12; G14; G18; C53

\footnotetext{
${ }^{1}$ Associate Professor. College of Business and Public Administration, University of North Dakota. Address: 293 Centennial Drive, Gamble Hall 290, Grand Forks, ND-58202. Email: psimlai@business.und.edu; Ph.: 1-701-7773360; Fax: 1-701-777-3365.
} 


\section{Introduction}

The idea that portfolios of stocks with high fundamental-to-price ratios outperform portfolios of stocks with correspondingly low fundamental-to-price ratios can be dated back to the work of Graham and Dodd (1934). Since then numerous studies have demonstrated that the spread in returns between value stocks (characterized by high book-to-market, high earnings-to-price, high cash-flow-to-price, and low past sales growth) and growth stocks (characterized by low book-tomarket, low earnings-to-price, low cash-flow-to-price, and high past sales growth) is significant in the U.S. and non-U.S. stock markets (see e.g., Chan and Lakonishok (2004), Fama and French (2008, 2012), Asness, Moskowitz, and Pedersen (2013) and references cited therein). It is also widely recognized that the value premium, the average return of value stocks minus the average return of growth stocks, is countercyclical and thus tends to be higher (lower) in weaker (stronger) economic times ${ }^{2}$.

In this paper, we ask whether a new measure of ex-ante volatility $(E A V)$ in stock returns contains relevant information about the cross-sectional variation in the value premium. Following Braun, Nelson, and Sunier (1995), we use a bivariate exponential GARCH (EGARCH) model that includes the unexpected component of the market return in each asset's covariance structure and estimate $E A V$. Compared to the existing literature, our $E A V$ measure contains traditional nonmarket (or idiosyncratic) risk as well as the unexpected component of market return. In contrast to ex-post volatility $(E P V)$, which is measured by sum of the squared and one lagged crosscovariance of daily realized returns, we estimate conditional volatility model based on the data up through month $t-1$ and obtain $E A V$ for each month $t$. Even though the use of residual volatility estimated from the market model or the Fama-French (1993) 3-factor model is quite well known (see e.g., Ali, Hwang, and Trombley (2003), Spiegel and Wang (2005), and Bali and Cakici (2008)), typically the result is a measure of estimated volatility that is independent of the market volatility. We avoid using the multifactor model to generate residual variance, and our

\footnotetext{
2 See for example, Gomes et al. (2003), Petkova and Zhang (2005), Zhang (2005), Avramov and Chordia (2006), and Gulen et al. (2011).
} 
parsimonious specification allows an estimate of the time-varying measure of $E A V$ that is out-ofsample and not independent of shocks to the market. Our specification also renders a channel through which volatilities of different assets can move together and incorporates the asymmetric response of market volatility change.

Our empirical findings suggest that there is a positive average compensation for the estimated conditional volatility risk. Specifically, we find that there is an economically significant positive relation between our estimated $E A V$ measure and the expected returns of portfolios of stocks characterized by size $(M E)$ and book-to-market $(B E / M E)$ ratio. We demonstrate that our $E A V$ measure is a more important determinant of average stock returns than has previously been shown. The benefit of the new measure is that it is countercyclical and contains relevant information about the time-variation in value premium. We show that, at the portfolio level, the cross-sectional dispersion in average stock returns is positively related to the estimated value of $E A V$ and therefore can serve as a state variable. The monthly average $E A V$ risk premia across the value-growth dimension range from $0.21 \%$ to $0.07 \%$ during the post-1963 period. Our crosssectional result is robust across various sub-periods, and is significant after controlling for various firm characteristics, common risk factors, and macroeconomic risk. Our empirical evidence adds to the understanding of the driving forces behind the value premium.

Despite the consensus on the subsistence of superior returns of value stocks, there are many different explanations for the existence of value premium. The first story based on the behavioral arguments (e.g., De Bondt and Thaler (1987), and Lakonishok, Shleifer, and Vishny (1994) etc.) suggests cognitive biases and investors' over-reaction as the main source of the value premium. The second story, which is based on the risk-based explanations (e.g., Chan and Chen (1991), Fama and French (1996, 1998, 2006), and Chen and Zhang (1998)), argue that the value premium results from rational variations of expected returns ${ }^{3}$. Ali, Hwang, and Trombley (2003) conclude that the $B E / M E$ effect is greater for stocks with higher idiosyncratic return volatility,

\footnotetext{
${ }^{3}$ In other related works, Ferguson and Shockley (2003) suggest that the observed size and value effects occur because estimation errors in proxy betas are correlated with relative distress. Recently, Campbell et al. (2010) argue that the systematic risks of value and growth stocks are determined by the properties of their cash-flows. Cooper and Gubellini (2011) show that common anomalies such as the value effect are not due to risk, but Guo et al. (2009) argue that the value premium is a proxy for timevarying investment opportunities.
} 
and the view is consistent with the market-mispricing explanation for the value anomaly ${ }^{4}$. Some recent researchers such as Liew and Vassalou (2000), Vassalou (2003), Hahn and Lee (2006) and Petkova (2006) have related value premium with macroeconomic factors such as future GDP growth. Chen, Petkova, and Zhang (2008) argue that the expected value premium is weakly responsive to shocks to aggregate economic conditions.

In view of the existing evidence on the mispricing patterns and interpretations, we intend to seek an alternative explanation for the value-growth return anomaly through ex-ante risk factors. More specifically, we investigate whether the $E A V$ of each asset can complement the role of common risk factors as a parsimonious risk measure, and in the process disentangle a part of the mispricing patterns. Unlike the previous studies, which almost always use ex-post market ( $E P M)$ returns in the cross-section, in our asset pricing tests we incorporate a proxy for the ex-ante market $(E A M)$ risk, which is not independent of aggregate economic conditions, and this proxy enables us to exploit a novel method using publicly available data. We regress the realized market return at time $t$ on four macroeconomic variables from period $t-1$ and use the fitted value to calculate the $E A M$ risk - a measure of the estimated expected market risk premium. The use of market segmentation procedures as advocated by Pettengill, Sundaram, and Mathur (1995) provides additional support for the existence of a significant relationship between average returns and $E A V$ betas. We find that the value premium is higher during weaker economic times, which coincides with states of the world with high- $E A V$ and high expected market risk premium. Our empirical evidence is consistent with the explanation that countercyclicality of value premium is more pronounced in more volatile times. Risky assets with higher $E A V$ have higher expected returns. Even though we are not the first to study the value-growth anomaly using aggregate risk factors, our alternative methodology to explain the cross-sectional variation in expected stock returns, which is associated with the $E A V$ and the expected market risk premium, adds to the literature.

Our paper is closely related to a number of existing works, which show the time-series and crosssectional relationship between idiosyncratic volatility (IVOL), a well-known ex-ante measure of volatility, and returns. Despite the notoriety of the concept, there is a lack of consistency in the

\footnotetext{
${ }^{4}$ The third story relates the value premium to sample selection bias and data snooping bias. Works by Chan et al. (1995), Davis (1994), and Fama and French $(1996,2008)$ refute such empirical claims.
} 
definition of IVOL because its measure can be model-dependent. Some authors, notably Ang, Hodrick, Xing, and Zhang (2006, 2009 AHXZ hereafter), use total IVOL, and some others, such as Fu (2009), use expected IVOL. In addition to the definition, there is also a strong debate in the literature about the cross-sectional pricing ability of $I V O L^{5}$. For example, Lehmann (1990), Spiegel and Wang (2005), and Fu (2009) find that volatility is positively related to the crosssection of stock returns. In contrast, Bali and Cakici (2008) conclude that there is no significant, robust relation between volatility and returns. AHXZ (2006, 2009), on the other hand, demonstrate that stocks with high IVOL have abysmally low average returns ${ }^{6}$. This negative relation between idiosyncratic risk and future stock returns is in sharp contrast to other findings ${ }^{7}$. Recently, Miffre, Brooks, and Li (2013, p.78) find that “investors demand an additional return for bearing the IVOL of poorly-diversified portfolios.” Chen and Petkova (2012) suggest that average stock variance is a factor missing from the IVOLs calculated from the Fama-French 3factor model. They show that the innovations in average stock variance represent a priced risk factor in the cross-section of stock returns.

It has been known for a long time that volatilities of individual assets can move together (Black (1976)), and respond asymmetrically with positive and negative changes in market risk (Braun, Nelson, and Sunier (1995)). Our analysis combines such insights from both the volatility and the asset-pricing literature. Compared to the existing studies, we estimate the volatility of individual assets using their historical returns and the unexpected component of the market return. To the best of our knowledge, there is no measure of IVOL in the literature that incorporates both of these issues.

\footnotetext{
${ }^{5}$ At the aggregate level, there are a number of interesting works. For example, Goyal and Santa-Clara (2003), Bali et al. (2005), and Guo and Savickas (2010) study the relation between the average IVOL and stock market return. Adrian and Rosenberg (2008) show that shocks to systematic volatility are important determinants of equity returns, and the price of risk is negative for both short- and long-run volatility components.

${ }^{6}$ In terms of methodological issues, AHXZ's results have been challenged in many papers. Fu (2009) argues that a typical stock's $I V O L$ process is not a random walk and a better measure is needed to capture the time-varying property of $I V O L$. Fu (2009) and Huang et al. (2010) point out that return reversals from stocks with high idiosyncratic risk in the last month lead to AHXZ's results.

${ }^{7}$ In related work, Baker and Wurgler (2006) argue that when investors' sentiment at the end of the previous year is low (high), high volatility stock will earn high (low) returns in the current year. Li et al.(2009) find that the time-series of value premia is strongly and positively correlated with its volatility. Grullon et al. (2012) provide evidence that the positive relation between firm-level stocks returns and firm-level return volatility is due to firms' real options.
} 
The rest of this article is organized as follows. In section 2 we describe the data and provide an overview of different measures of volatility used in the paper. Section 3 is the main section of the article and provides an evaluation of factor prices of risk in the presence of the $E A V$ measure. It includes our main cross-sectional regression results using benchmark portfolios, an evaluation of several robustness tests, and an investigation of the price of $E A V$ risk in up and down markets. Section 4 contains some interpretations and section 5 concludes.

\section{Sample and empirical methodology}

In this section we describe the sample and provide a brief overview of our ex-post and ex-ante measures.

\subsection{Data}

We combine and analyze various sets of data in this paper. For the testing assets, we use two sets of value-weighted daily and monthly portfolio returns obtained from Ken French: 6 portfolios formed on size- and book-to-market-ratios, and 25 portfolios formed on size- and book-tomarket-ratios. Our sample starts in July 1963 because the daily data for the 6 size- and book-tomarket-sorted portfolios were unavailable prior to then ${ }^{8}$. For the ex-post market proxy $\left(R_{M}\right)$, we utilize the return of CRSP's value-weighted index on all NYSE, AMEX, and NASDAQ stocks. We also employ four macroeconomic variables in the asset pricing tests and in the evaluation of the expected market risk premium. The variables are - the aggregate dividend yield (DIV), default spread (between Moody's Baa and Aaa corporate bonds or $D E F$ ), term spread (between the ten-year and the one-year Treasury bond or TERM), and short-term interest rate (one-month Treasury bill rate or $R_{f}$ ). We obtain the bond yields from the Federal Reserve Bank of St. Louis.

\subsection{Ex-post and ex-ante measures}

Following French, Schwert, and Stambaugh (1987) we calculate the EPV measure by

\footnotetext{
${ }^{8}$ At the time the paper was written, the daily data for Fama-French factors were available on Ken French data library starting July 1, 1963.
} 


$$
\sigma_{i, t}=\sqrt{\sum_{i=1}^{N_{t}} r_{i, t}^{2}+2 \sum_{i=2}^{N_{t}} r_{i, t} r_{i-1, t}}
$$

where $N_{t}$ is the number of trading days in month $t$ and $r_{i, t}$ is the return on the $i$ th day of month $t$. Since the excess market return and the benchmark volatility measures are based on the realized rate of return, we call them ex-post measures. We calculate the ex-ante measure of market risk from the fitted value of the following regression

$$
R_{M, t}=\delta_{0}+\delta_{1} D I V_{t-1}+\delta_{2} D E F_{t-1}+\delta_{3} T E R M_{t-1}+\delta_{4} R_{f, t-1}+\eta_{M, t}
$$

where the set of dependent and explanatory variables are as defined in subsection 2.1. It is well known that the resulting estimate of the expected market risk premium from (2), which we refer as $E A M$ throughput the paper, is higher in bad times and lower in good times, and its presence help us to evaluate the countercyclical price of risk (see e.g., Petkova and Zhang (2005)).

We use the bivariate EGARCH method to estimate conditional variance of each of the 25 sizeand book-to-market-sorted portfolios, and use them in the cross-sectional regressions. In order to estimate the ex-ante conditional variances, we use the following specifications

$$
\begin{gathered}
\ln \left(\sigma_{M, t}^{2}\right)=\alpha_{M, t}+\delta_{M, t}\left[\ln \left(\sigma_{M, t-1}^{2}\right)-\alpha_{M, t}\right]+\theta_{M, t} z_{M, t-1}+\gamma_{M, t}\left[\left|z_{M, t-1}\right|-E\left|z_{M}\right|\right] \\
\ln \left(\sigma_{i, t}^{2}\right)=\alpha_{i, t}+\delta_{i, t}\left[\ln \left(\sigma_{i, t-1}^{2}\right)-\alpha_{i, t}\right]+\theta_{i, t} z_{i, t-1}+\gamma_{i, t}\left[\left|z_{i, t-1}\right|-E\left|z_{i, t-1}\right|\right]+\theta_{i, M, t} z_{M, t-1}+ \\
\gamma_{i, M, t}\left[\left|z_{M, t-1}\right|-E\left|z_{M}\right|\right]
\end{gathered}
$$

The interpretation of the coefficients and the intuition of the functional forms of (3) and (4) are similar to Braun, Nelson, and Sunier (1995). The presence of $\theta_{i, M}$ and $\gamma_{i, M}$ allows the asset $i$ 's conditional variance to respond asymmetrically to positive and negative market returns. If the estimated slope coefficients $\theta_{i, M}$ and $\gamma_{i, M}$ are non-zero, the set-up allows contemporaneous correlation between changes in $\ln \left(\sigma_{M, t}^{2}\right)$ and $\ln \left(\sigma_{i, t}^{2}\right)$. For the empirical implementation, $z_{M, t}$ is the standardized demeaned return for the market portfolio and is calculated as $z_{M, t}=\bar{r}_{M, t} / \sigma_{M, t}$, where $\bar{r}_{M, t}$ is the demeaned return of the market portfolio. Also, $z_{i, t}$ is the standardized residual 
for the $i$ th asset and is calculated as $z_{i, t}=\left(\bar{r}_{i, t}-\beta_{i, t} \bar{r}_{M, t}\right) / \sigma_{i, t}$, where $\bar{r}_{i, t}$ is the demeaned return of the $i$ th asset ${ }^{9}$.

In the traditional approach of GARCH modeling, researchers consider the square residual, which reflects the diversifiable, or unsystematic risk of asset $i$. In contrast, through (3) and (4), we allow a linkage between the portfolio-level volatility and the unexpected component of the aggregate market return, as an unexpected change in market return is likely to affect contemporaneous and future portfolio-level stock returns. In all of our empirical tests, we implement specifications (3) - (4) independently for each asset and use the resulting one-monthahead expected $E A V$ from an estimated model ${ }^{10}$. Following Fu (2009), we estimate all models using an expanding window of data with a requirement of 3 years (i.e., 36 months) of minimum observations. This helps us to avoid a look-ahead bias problem that emerges as a result of using full period data (French, Schwert, and Stambaugh (1987)) $)^{11}$.

It is important to recognize that there exists a multitude of GARCH models and our choice of the bivariate EGARCH based specification is not arbitrary. The goal is to select a model that welldescribes the time-series property of our testing assets. In the literature, there are a number of studies that support the relevance of the EGARCH specification in modeling conditional volatilities $^{12}$. The main difference between our work and the existing literature is that we use a bivariate version of EGARCH that includes the unexpected component of the market return in

\footnotetext{
${ }^{9}$ Note that in (3) and (4), we use a parsimonious approximation of the conditional distribution of the residual term in order to implement time-varying property of total volatility. Equations (3) and (4) resemble the familiar EGARCH model introduced by Nelson (1991), with the exception that in (4) we utilize the standardized unexpected returns on the market portfolio in our conditional variance generating process of asset $i$.

${ }^{10}$ We use various maximum log-likelihood and information criterion to select the specification of conditional volatilities. Consistent with existing literature, we find that conditionally log-normal models of volatility perform better than square root or affine volatility specifications. The addition of lags does not drive our final results. We also implemented a slight different version of the EGARCH model by assuming that $\ln \left(\sigma_{i, t}^{2}\right)=\alpha_{i, t}+\delta_{i, t}\left[\ln \left(\sigma_{i, t-1}^{2}\right)-\alpha_{i, t}\right]+\theta_{i, t} z_{i, t-1}+\gamma_{i, t}\left[\left|z_{i, t-1}\right|-\right.$ $\left.E\left|z_{i, t-1}\right|\right]+\delta_{i, M, t}\left[\ln \left(\sigma_{M, t-1}^{2}\right)-\alpha_{M, t}\right]+\theta_{i, M, t} z_{M, t-1}+\gamma_{i, M, t}\left[\left|z_{M, t-1}\right|-E\left|z_{M}\right|\right]$. Our main findings are unaffected by any such specification.

${ }^{11}$ We also estimate bivariate EGARCH model parameters using the full period data and compute expected volatility. The results are qualitatively similar to the ones presented in this paper.

${ }^{12}$ For example, Pagan and Schwert (1990) show that EGARCH is the best in overall performance for monthly U.S stock returns. Engle and Mustafa (1992) find that EGARCH is one of the best models to perform modeling conditional variance based on the observed prices for stock options. Engle and $\mathrm{Ng}$ (1993) find that EGARCH does a good job in capturing the asymmetry of conditional volatilities. Recently, Adrian and Rosenberg (2008) explore the cross-sectional pricing of volatility risk using a two component EAGRCH model. In order to capture the time-varying property of idiosyncratic risk, Fu (2009) employ EGARCH models to estimate the expected $I V \mathrm{~s}$.
} 
each asset's covariance structure. Also, we don’t use a multifactor model to generate predicted residuals. In the next section we describe the main findings of the paper.

\section{Empirical findings using the benchmark portfolios}

Can we substantiate the role of $E A V$ measure at the portfolio level? How can we rationalize the result of positive or negative correlation between $E A V$ risk and the value premium? In this section we address such important issues and evaluate the role of $E A V$ measure using the widely known Fama-French (1993) testing assets consisting of 25 size- and book-to-market-sorted portfolios.

\subsection{Cross-sectional regressions and the incremental explanatory power of ex-ante volatility}

We employ two-stage Fama and MacBeth (1973) methodology in our cross-sectional asset pricing tests using 25 size- and book-to-market-sorted portfolios. Following the standard convention, for each portfolio $i$, we first obtain the factor loadings from the time-series regressions. The portfolio returns are then regressed each month $(t=1, \ldots T)$, cross-sectionally, on the combined set of factor sensitivities and predetermined attributes of the portfolios by the following specification

$$
r_{i, t}=\gamma_{0, t}+\gamma_{1, t} \hat{\beta}_{i, t}+\sum_{j=2}^{K} \gamma_{j, t} Q_{i, j, t}+\eta_{i, t}
$$

where $r_{i, t}$ is the realized excess return of portfolio $i, \hat{\beta}_{i, t}$ is the estimated slope coefficient of $E P M$ (or $E A M$ ) and used as the first independent variable in (5). The set of $K-1$ explanatory variables $Q_{i, j, t}$ incorporates the additional independent variables of cross-sectional expected returns. It includes the loadings of size and value factors (SMB and $H M L)$, the estimated $E A V$, the estimated $E P V$, the momentum factor (MOM), and four macroeconomic state variables $(D E F, T E R M, R F$, and $D I V)$. The explanatory variables also include the size and value characteristics (i.e., $\ln ($ Size $)$ and $\ln (B E / M E)$ ) that we only append in the cross-section. To test the hypothesis that the expected coefficient is zero, we form t-statistics defined as the time-series average of the monthly cross-sectional regression (CSR) coefficients divided by the standard 
error of the mean. All the standard errors for the $\gamma$ terms are adjusted for heteroskedasticity and autocorrelation.

We report our first set of Fama-MacBeth (1973) CSR results in Table 1. We compute the full sample factor loadings in one univariate or multivariate (as needed) time-series regression, and use the loading as independent variables in the second pass. All model yield statistical evidence that, in the cross-section, $E A V$ is positively related to average return of the 25 size- and book-tomarket-sorted portfolios. In the univariate regression (model 1), the slope coefficient of $E A V$ is 2.19 with a t-statistic of 4.58. When we control for EPM (model 2) or Fama-French factors (model 3), the magnitude of $E A V$ 's slope coefficient decreases but remains positive and significant at the $1 \%$ level. When we augment our benchmark model with the size and value risk factors (model 3 and 5), only $H M L$ and $E A V$ become significant at the 1\% level (model 3).

We find that, even after controlling for ex-ante market risk (model 4 and 5) and four macroeconomic state variables (model 6 and 7), there is a positive and significant association between portfolio returns and the contemporaneous value of $E A V$, which is consistent with the view that the $E A V$ risk carries a positive risk premium. Except for model 3 and 7, we obtain large positive values for the intercept term in all of the CSR's. It is interesting that neither expost nor ex-ante market risk is priced in the cross-section ${ }^{13}$. In the last two columns we report the adjusted $R^{2}$ as well as the root-mean-squared errors ( $\left.R M S E\right)$ to evaluate the pricing performance of different models. Altogether, we find that the inclusion of Fama-French factors produces higher $\bar{R}^{2}$ and lower $R M S E$ values.

To better understand the cross-sectional nature of the factor loadings and the prices of risk, we take a closer look at the factor premia of each portfolio. The results are reported in Table 2. We find that, consistent with the existing literature, compared to the growth stocks, the value stocks

\footnotetext{
${ }^{13}$ It is important to note that, somewhat deviating from the conventional asymmetric GARCH type models, the bivariate EGARCH model in this paper allows for asymmetric effects of the standardized unexpected returns for the market portfolio on asset's conditional volatility (i.e., the last two terms on the right-hand side of equation (6)). Existing work such as Fu (2009) has shown that the conditional volatility estimated from the EGARCH model without invoking market returns predicts higher expected returns in the cross-section. In unreported results, we find that the positive cross-sectional relation between $E A V$ and expected stock returns doesn't exists in our sample if the standardized unexpected component of the market portfolio is excluded in the EGARCH model, and it suggests that the return predictability of $E A V$ is contributed by these two additional terms in equation. So the positive pricing effect of $E A V$ as a state variable that indeed underlies the value premium may not have been oversold.
} 
have higher average returns and slightly lower market betas ${ }^{14}$. The average market risk premium for all portfolio is $0.42 \%$, and the average risk premium for the $E A V$ component is $0.17 \%$. Even after controlling for market return, the value stocks have higher exposure to $E A V$ risk than the growth stocks. Compared to the market risk premia, there is a larger spread in the $E A V$ risk premia between the value and the growth stocks $(0.21 \%-0.07 \%=0.14 \%)$. Similarly, the small size stocks have a bigger spread in the $E A V$ risk premia over the big size stocks $(0.29 \%-0.00 \%$ $=0.29 \%$ ). Since the monthly average returns of a long value and short growth zero-investment portfolio is $0.14 \%$, a two-factor model with $E P M$ and $E A V$ predicts average returns of value stocks that are higher than the benchmark market model.

\subsection{Robustness tests}

In order to understand whether our previous CSR results are simply an artifact unique to the sample period and model specifications, we next perform a comprehensive set of robustness tests. We examine whether the positive relationship between average stocks returns and the $E A V$ remains valid for different sub-sample periods, and are sensitive to the inclusion of additional risk factors, firm-level characteristics and regression estimation methods.

We first perform the sub-period analysis and re-estimate all the models of Table 1 for four different sample periods. The results (reported in Table A1 of appendix) suggests that, even for various sub-periods and alternative model specifications, the $E A V$ risk factor is playing an independent role and does not seem to be influenced by the common sources of risk such as Fama-French factors. In fact, the $E A V$ risk factor obtains a stable positive and statistically significant risk premium over all four sub-sample periods, thereby strengthening its role as an

\footnotetext{
${ }^{14}$ For the two-factor model, with $E P M$ and $E A V$ as two potential factors, eighteen out of twenty-five portfolios generate positive and statistically significant time-series slopes for the $E A V$. The average loading on $E A V$ for the value quintile is 0.12 , while for the growth quintile it is 0.04 .
} 
additional state variable. This also reaffirms that the value and small size firms earn more simply because they are riskier ${ }^{15}$.

Second, some recent studies suggest that allowing a free intercept in the CSR can produce insignificant slope coefficient of the betas (see e.g., Savov (2011)). If the factor betas have little variation across the testing portfolios, the result is poorly estimated factor premia ${ }^{16}$. Such a lack of variation also creates a near multicollinearity problem between the vector of ones and the vector of stock market betas (Jagannathan and Wang (2007)). We therefore need to impose a restriction on the model by omitting the intercept and re-estimate our CSR to deliver more power. In Table A2 of appendix we report such results. The modified estimated CSR result shows that the role of $E A V$ is unaffected by any such restriction.

Finally, several existing works show that the firm-level characteristics and other common risk factors have significant effects in the CSR involving size- and book-to-market-sorted portfolios ${ }^{17}$. Therefore, it is important to know whether their presence have any influence on the cross-sectional characterization of the $E A V$ risk factor. It is also not clear what role the $E P V$ risk factor plays in the cross-section and whether it reigns on the $E A V$ effect at all. In Table A3 of the appendix we control for some of the additional variables and replicate the previous results of Table 1. We observe that the coefficient of $E A V$ remains statistically significant in the presence of $E P V$ and firm characteristics such as $\ln (\operatorname{size})$ and $\ln (B E / M E)$. Altogether, the battery of robustness test ensures that the significance our main cross-sectional results, obtained in Table 1 , is not specific to the sample period, the inclusion of the additional common risk factors, or the estimation methods used in the pricing tests.

\footnotetext{
${ }^{15}$ We also perform a series of CSR tests using non-overlapping subsamples. They include: July 1963 - June 1970; July 1970 June 1980; July 1980 - June 1990, July 1990 - June 2000, and July 2000 - June 2010. The results are qualitatively similar to the ones presented in the paper. We thank an anonymous referee for suggesting the non-overlapping CSR tests.

${ }^{16}$ In fact, in the literature, it is quite common to have a negative market risk premium for the 25 size- and book-to-market-sorted portfolios in the presence of a free constant (Jagannathan and Wang (2007), Kang et al. (2011)).

${ }^{17}$ For example, Jagannathan and Wang (2007) suggest that the inclusion of firm characteristics as additional explanatory variables in the CSR can aid in model misspecification tests.
} 


\subsection{Price of EAV risk in up and down market}

Given our findings so far, it is plausible that the price of ex-ante volatility varies over market conditions and business cycles. It is likely that the relation between the estimated $E A V$ and the average returns is dependent on the direction of $E P M$ or the expected market risk premium. As mentioned by Petkova and Zhang (2005), since the ex-post and the ex-ante market returns are positively correlated, what we identify as good states ex-post constitute bad states ex-ante, and vice versa, in terms of business cycles. Therefore, if the price of $E A V$ is sensitive to market conditions and business cycles, one should expect a different coefficient of $E A V$ in up and down markets. Moreover, if the value stocks expose investors to a greater downside risk, in the presence of ex-post up and down market indicators, the slope coefficient of $E A V$ should be higher during down markets and lower in up markets in the cross-section. Put through the lens of business-cycle categorization, the slope coefficient of $E A V$ should be lower in down ex-ante markets and higher in up ex-ante markets.

In Table 3, we conduct such an experiment. We follow the market segmentation procedures of Pettengill, Sundaram, and Mathur (1995) and eventually replicate our Table 1 results by incorporating up and down market dummies in the $\mathrm{CSR}^{18}$. We define two sets of dummies, one using the $E P M$ return, and another using the expected market risk premium or the $E A M$ return.

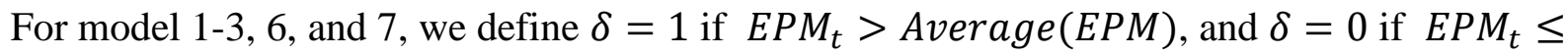
Average (EPM). For model 4 and 5, we define $\delta=1$ if $E A M_{t} \leq$ Average(EAM), and $\delta=0$ if $E A M_{t}>$ Average $(E A M)$. The use of dummies led us to define two new variables, they are $E A V^{u p}=\delta * E A V$ and $E A V^{\text {down }}=(1-\delta) * E A V$.

Results from Table 3 reinforce the positive overall relation between $E A V$ and portfolio returns of 25 size- and book-to-market-sorted portfolios. As we expect, the intercept and the slope coefficient of all other variables except $E A V^{u p}$ and $E A V^{\text {down }}$ remain unchanged. The results, however, indicate that the trade-off between $E A V$ and average returns is different in up and down markets. When we define up and down market by the $E P M$ return, the slope coefficient of $E A V$ beta is always higher in bad times and lower in good times. For example, when we use $E A V$

\footnotetext{
${ }^{18}$ We also use up and down market dummies to replicate CSR's without an intercept (unreported) and obtain qualitatively similar results. Details are available upon request.
} 
alone, the slope coefficient is 0.31 for $E A V^{u p}$ (with an insignificant t-statistic of 1.54) and 1.33 for $E A V^{\text {down }}$ (with a significant t-statistic of 5.15). For all 5 models (i.e., models 1-3, 6, and 7), which include the EPM return-based dummy, we observe lower coefficients for up-market betas and higher coefficients for down-market betas. Therefore, once betas are allowed to vary with the market, we find clear evidence that the documented positive relation between $E A V$ and average returns is mainly due to the better performance of high- $E A V$ stocks during months when the market is down.

In models 4 and 5 of Table 3, we re-evaluate the cross-sectional role of $E A V$ by conditioning on low and high expected market risk premium. The results shows that the $E A V$-return relation is still asymmetrical, but now the coefficient of $E A V^{u p}$ is higher and economically stronger than the coefficient of $E A V^{\text {down }}$. In other words, once the dummy variable is redefined using the expected market risk premium, we find that the positive $E A V$-return relation still persists and is mainly due to the impressive performance of value stocks during good states ex-ante, which is nothing but bad states ex-post. It is apparent that the value premium is higher during weaker economic times, which coincides with states of the world with high ex-ante volatility and high expected market risk premium. Therefore, our empirical evidence is consistent with the explanation that countercyclicality of value premium is more pronounced in more volatile times $^{19}$.

\section{Interpretation of the results}

The empirical findings of this paper are consistent with the existing evidence on the positive relation between average return and IVOL (Ali, Hwang, and Trombley (2003), Goyal and SantaClara (2003), Ghysels, Santa-Clara, and Valkanov (2005), Fu (2009), Miffre, Brooks, and Li (2013)), and contrasts with the evidence that shows a negative relation (AHXZ (2006, 2009), Guo and Savickas (2010)). The obvious question is why does our measure of the ex-ante volatility constituent explain the average portfolio returns of value-growth stocks? One possible

\footnotetext{
${ }^{19}$ It is well known that the market return is a very noisy state proxy. Following the literature, we also examine the robustness of the findings using alternative definition of up and down markets that uses the expansionary and recessionary periods defined by the NBER. Our results are consistent with these alternative definitions of up and down markets.
} 
explanation is that our new $E A V$ measure, which is augmented by the unexpected component of market return, is related to a risk factor that is missing from the static version of the market model. This explanation goes along well with the recent argument proposed by Chen and Petkova (2012). The missing risk factor correlates with the conditional volatility of the value premium and possibly with the real economy, and can serve as a state variable (Merton (1987)). It also responds asymmetrically with positive and negative changes in market risk as suggested by Braun, Nelson, and Sunier (1995).

What is the precise nature of the ex-ante risk factor? To better understand it, we offer timevarying risk as a potential explanation. Our primary finding that the value premium and its conditional volatility are positively correlated is consistent with the notion, put forward by Kogan (2004) and Zhang (2005), that capital investment is irreversible. Using a general equilibrium model, Kogan (2004) investigates the relationship between financial asset prices and real investment. He finds that the conditional volatility of stock returns is stochastic and is a function of the state of the economy. Because of irreversibility and adjustments costs, the relationship between $B E / M E$ and conditional volatility becomes nonmonotoic. When the $B E / M E$ ratio is low, it has a negative relationship with volatility, and when the $B E / M E$ ratio is high, the relationship is positive. Because of costly irreversibility, the conditional volatility of value firms is more countercyclical than that of growth firms.

Zhang (2005) proposes an economic mechanism underlying the value premium using the asymmetric adjustment cost of capital. In bad times, value firms face more difficulty than growth firms in downsizing capital. Since the dividend streams of value stocks fluctuate more than those of growth firms in economic downturns, there is asymmetric conditional risk dispersion between value and growth stocks. In sum, the costly irreversibility causes the value firms to be countercyclical and growth firms to be procyclical. Therefore, our findings can be explained by the theoretical predictions of the models of Kogan (2005) and Zhang (2005); the reason that the value premium and its conditional volatility are correlated is because they are both countercyclical. The value premium is a compensation for time-varying risk and is proxied by our predicted $E A V$ measure, which relates to differences in costly irreversibility and adjustment costs that the value and growth firms experience during economic downturns. 


\section{Conclusions}

This paper contributes to the linkage between the average returns of value-growth firms and an ex-ante measure of total volatility risk. We find that the return of the 25 size- and book-tomarket-sorted Fama-French portfolios and their ex-ante volatility measure, as captured by a modified bivariate EGARCH framework, are positively correlated. We argue that the ex-ante volatility risk factor is acting as a proxy for time-varying risk and contributing to the debate on the possible role of missing risk factors in explaining average stock returns. Future research can focus on broad definition of value firms and see whether the ex-ante volatility risk is priced in those assets. The incorporation of additional factors that drive expected portfolio returns in the constituents of ex-ante volatility would be another interesting avenue for possible research.

\section{References}

Ali, A., Hwang, L. S., \& Trombley, M. A. (2003). Arbitrage risk and the book-to-market anomaly. Journal of Financial Economics, 69, 355-373.

Asness, C. S., Moskowitz, T. J., \& Pedersen, L. H. (2013).Value and momentum everywhere. Journal of Finance, 68, 929-985.

Adrian, T., \& Rosenberg, J. (2008). Stock returns and volatility: Pricing the short-run and long-run components of market risk. Journal of Finance, 63, 2997-3030.

Ang, A., Hodrick, R.J., Xing, Y., \& Zhang, X. (2006). The cross-section of volatility and expected returns. Journal of Finance, 61, 259-299.

Ang, A., Hodrick, R.J., Xing, Y., \& Zhang, X. (2009). High idiosyncratic volatility and low returns: International and further U.S. evidence. Journal of Financial Economics, 91, 1-23.

Avramov, D., \& Chordia, T. (2006). Asset pricing models and financial market anomalies. Review of Financial Studies, 19, 1001-1040.

Baker, M., \& Wurgler, J. (2006). Investor sentiment and the cross-section of stock returns. Journal of Finance, 61, 1645-1680.

Bali, T.G., \& Cakici, N. (2008). Idiosyncratic volatility and the cross section of expected returns. Journal of Financial and Quantitative Analysis, 43, 29-58.

Bali, T.G., Cakici, N., Yan, X., \& Zhang, Z. (2005). Does idiosyncratic risk really matter?. Journal of Finance, 60, 905-929. 
Black, F. (1976). Studies of stock market volatility changes. Proceedings of the American Statistical Association, Business and Economic Statistics Section, 177-181.

Braun, P.A., Nelson, D.B., \& Sunier, A.M. (1995). Good news, bad news, volatility, and betas. Journal of Finance, 50, 1575-1603.

Campbell, J.Y., Polk, C., \& Vuolteenaho, T. (2010). Growth or glamour? Fundamentals and systematic risk in stock returns. Review of Financial Studies, 23, 305-344.

Chan, K.C., \& Chen, N. (1991). Structural and return characteristics of small and large firms. Journal of Finance, 46, 1467-1484.

Chan, L.K.C., Jegadeesh, N., \& Lakonishok, J. (1995). Evaluating the performance of value versus glamour stocks The impact of selection bias. Journal of Financial Economics, 38, 269-296.

Chan, L.K.C., \& Lakonishok, J. (2004). Value and growth investing: Review and update. Financial Analysts Journal, 60, 71-86.

Chen, L., Petkova, R., \& Zhang, L. (2008). The expected value premium. Journal of Financial Economics 87, 269-280.

Chen, N., \& Zhang, F. (1998). Risk and return of value stocks. Journal of Business, 71, 501-535.

Chen, Z., \& Petkova, R. (2012). Does idiosyncratic volatility proxy for risk exposure?. Review of Financial Studies, 25, 2745-2787.

Cooper, M.J., \& Gubellini, S. (2011).The critical role of conditioning information in determining if value is really riskier than growth. Journal of Empirical Finance, 18, 289-305.

Davis, J.L. (1994). The cross-section of realized stock returns: The Pre-COMPUSTAT Evidence. Journal of Finance, 49, 1579-1593.

DeBondt, W. F. M. \& Thaler, R. H. (1987). Further evidence on investor overreaction and stock market seasonality. Journal of Finance, 42, 557-581.

Engle, R.F., \& Mustafa, C. (1992). Implied ARCH models from options prices. Journal of Econometrics, 52, 289-311.

Engle, R.F., \& Ng, V.K. (1993). Time-varying volatility and the dynamic behavior of the term structure. Journal of Money, Credit and Banking, 25, 336-349.

Fama, E.F., \& French, K.R. (1993). Common risk factors in the returns on stocks and bonds. Journal of Financial Economics, 33, 3-56.

Fama, E.F., \& French, K.R. (1996). Multifactor explanations of asset pricing anomalies. Journal of Finance, 51, 55-84. 
Fama, E.F., \& French, K.R. (1998). Value versus growth: The international evidence. Journal of Finance, 53, 1975-1999.

Fama, E.F., \& French, K.R. (2006). The value premium and the CAPM. Journal of Finance, 61, 21632185.

Fama, E. F., \& French, K. R. (2008). Dissecting anomalies. Journal of Finance, 63, 1653-1678.

Fama, E.F., \& French, K.R. (2012). Size, value, and momentum in international stock returns. Journal of Financial Economics, 105, 457-472.

Fama, E.F., \& MacBeth, J.D. (1973). Risk, return and equilibrium: Empirical tests. Journal of Political Economy, 81, 607-636.

Ferguson, M.F., \& Shockley, R.L. (2003). Equilibrium "Anomalies". Journal of Finance, 58, pp. 25492580.

French, K.R., Schwert, G.W., \& Stambaugh, R.F. (1987). Expected stock returns and volatility. Journal of Financial Economics, 19, 3-29.

$\mathrm{Fu}, \mathrm{F}$. (2009). Idiosyncratic risk and the cross-section of expected stock returns. Journal of Financial Economics, 91, 24-37.

Gomes, J., Kogan, L., \& Zhang, L. (2003). Equilibrium cross section of returns. Journal of Political Economy, 111, 693-732.

Goyal, A., \& Santa-Clara, P. (2003). Idiosyncratic risk matters!. Journal of Finance, 58, 975-1007.

Graham, B., \& Dodd, D.L. (1934). Security analysis. Whittlesey house, McGraw-Hill book company, inc.: New York.

Grullon, G., Lyandres, E., \& Zhdanov, A. (2012). Real options, volatility, and stock returns. Journal of Finance, 67, 1499-1537.

Gulen, H., Xing, Y., \& Zhang, L. (2011). Value versus growth: Time-varying expected stock returns. Financial Management, Summer, 381-407.

Guo, H., \& Savickas, R. (2010). Relation between time-series and cross-sectional effects of idiosyncratic variance on stock returns. Journal of Banking and Finance, 34, 1637-1649.

Guo, H., Savickas, R., Wang, Z., \& Yang, J. (2009). Is the value premium a proxy for time-varying investment opportunities? Some time-series evidence. Journal of Financial and Quantitative Analysis, 44, 133-154.

Hahn, J., \& Lee, H. (2006). Yield spreads as alternative risk factors for size and book-to-market. Journal of Financial and Quantitative Analysis, 41, 245-269. 
Huang, W., Liu, Q., Rhee, S.G., \& Zhang, L. (2010). Return reversals, idiosyncratic risk, and expected returns. Review of Financial Studies, 23, 147-168.

Jagannathan, R., \& Wang, Y. (2007). Lazy investors, discretionary consumption, and the cross-section of stock returns. Journal of Finance, 62, 1623-1661.

Kang, J., Kim, T.S., Lee, C., \& Min, B. (2011). Macroeconomic risk and the cross-section of stock returns. Journal of Banking \& Finance, 35, 3158-3173.

Kogan, L. (2004). Asset Prices and Real Investment. Journal of Financial Economics, 73, 411-431.

Lakonishok, J., Shleifer, A., \& Vishny, R.W. (1994). Contrarian investment, extrapolation, and risk. Journal of Finance, 49, 1541-1578.

Lehmann, B. (1990). Residual risk revisited. Journal of Econometrics, 45, 71-97.

Li, X., Brooks, C., \& Miffre, J. (2009).The value premium and time-varying volatility. Journal of Business Finance and Accounting, 36, 1252-1272.

Liew, J., \& Vassalou, M. (2000). Can book-to-market, size and momentum be risk factors that predict economic growth?. Journal of Financial Economics, 57, 221-245.

Merton, R.C. (1987). A simple model of capital market equilibrium with incomplete information. Journal of Finance, 42, 483-510.

Miffre, J., Brooks, C., \& Li, X. (2013). Idiosyncratic volatility and the pricing of poorly-diversified portfolios. International Review of Financial Analysis, 30, 78-85.

Nelson, D.B. (1991). Conditional heteroskedasticity in asset returns: A new approach. Econometrica, 59, 347-370.

Pagan, A.R., \& Schwert, G.W. (1990). Alternative models for conditional stock volatility. Journal of Econometrics 3, 87-105.

Petkova, R. (2006). Do the Fama-French factors proxy for innovations in predictive variables?, Journal of Finance, 61, 581-612.

Petkova, R., \& Zhang, L. (2005). Is value riskier than growth?. Journal of Financial Economics, 78, 187202.

Pettengill, G.N., Sundaram, S., \& Mathur, I. (1995). The Conditional relation between beta and returns. Journal of Financial and Quantitative Analysis, 30, 101-116.

Savov, A. (2011). Asset pricing with garbage. Journal of Finance, 66, 177-201.

Shanken, J., \& Zhou, G. (2007). Estimating and testing beta pricing models: Alternative methods and their performance in simulations, Journal of Financial Economics, 84, 40-86. 
Spiegel, M., \& Wang, X. (2005). Cross-sectional variation in stock returns: Liquidity and idiosyncratic risk. Working paper, Yale University.

Vassalou, M. (2003). News related to future GDP growth as a risk factor in equity returns. Journal of Financial Economics, 68, 47-73.

Zhang, L. (2005). The value premium. Journal of Finance, 60, 67-103. 
Table 1: Cross-sectional regressions using ex-ante volatility: Sample period is between July 1963 and June 2010

\begin{tabular}{|c|c|c|c|c|c|c|c|c|c|c|c|c|}
\hline Model & $\begin{array}{l}\gamma_{0} \\
\text { Int }\end{array}$ & $\begin{array}{l}\gamma_{1} \\
E P M\end{array}$ & $\begin{array}{l}\gamma_{2} \\
S M B\end{array}$ & $\begin{array}{l}\gamma_{3} \\
H M L\end{array}$ & $\begin{array}{l}\gamma_{4} \\
E A V\end{array}$ & $\begin{array}{l}\gamma_{5} \\
E A M\end{array}$ & $\begin{array}{l}\gamma_{6} \\
D E F\end{array}$ & $\begin{array}{l}\gamma_{7} \\
\text { TERM }\end{array}$ & $\begin{array}{l}\gamma_{8} \\
R F\end{array}$ & $\begin{array}{l}\gamma_{9} \\
D I V\end{array}$ & $R M S E$ & $R^{2}\left(\bar{R}^{2}\right)$ \\
\hline 1 & $\begin{array}{l}0.54 * * * \\
(2.57)\end{array}$ & & & & $\begin{array}{l}2.19 * * * \\
(4.58)\end{array}$ & & & & & & 2.09 & $\begin{array}{l}0.12 \\
(0.08)\end{array}$ \\
\hline 2 & $\begin{array}{l}0.79 * * \\
(2.01)\end{array}$ & $\begin{array}{l}-0.32 \\
(-0.74)\end{array}$ & & & $\begin{array}{l}1.65^{* * *} \\
(4.18)\end{array}$ & & & & & & 1.63 & $\begin{array}{l}0.40 \\
(0.34)\end{array}$ \\
\hline 3 & $\begin{array}{l}0.13 \\
(0.36)\end{array}$ & $\begin{array}{l}-0.41 \\
(-0.97)\end{array}$ & $\begin{array}{l}0.76 \\
(1.51)\end{array}$ & $\begin{array}{l}2.39 * * * \\
(5.35)\end{array}$ & $\begin{array}{l}0.96 * * * \\
(2.65)\end{array}$ & & & & & & 1.51 & $\begin{array}{l}0.51 \\
(0.42)\end{array}$ \\
\hline 4 & $\begin{array}{l}0.46^{* *} \\
(2.43)\end{array}$ & & & & $\begin{array}{l}1.44^{* * *} \\
(3.36)\end{array}$ & $\begin{array}{l}0.10 \\
(0.85)\end{array}$ & & & & & 1.68 & $\begin{array}{l}0.37 \\
(0.31)\end{array}$ \\
\hline 5 & $\begin{array}{l}0.63 * * * \\
(3.51)\end{array}$ & & $\begin{array}{l}0.68 \\
(1.54)\end{array}$ & $\begin{array}{l}1.65 * * * \\
(2.57)\end{array}$ & $\begin{array}{l}0.96 * * * \\
(2.82)\end{array}$ & $\begin{array}{l}0.20 \\
(1.07)\end{array}$ & & & & & 1.62 & $\begin{array}{l}0.46 \\
(0.36)\end{array}$ \\
\hline 6 & $\begin{array}{l}0.86 * * * \\
(2.60)\end{array}$ & & & & $\begin{array}{l}1.83^{* * *} \\
(3.80)\end{array}$ & & $\begin{array}{l}0.03 * * * \\
(2.73)\end{array}$ & $\begin{array}{l}0.15^{* * *} \\
(4.12)\end{array}$ & $\begin{array}{l}-0.02 \\
(-0.25)\end{array}$ & $\begin{array}{l}0.01 \\
(0.22)\end{array}$ & 1.64 & $\begin{array}{l}0.47 \\
(0.34)\end{array}$ \\
\hline 7 & $\begin{array}{l}0.30 \\
(1.49)\end{array}$ & $\begin{array}{l}-0.32 \\
(-0.86)\end{array}$ & $\begin{array}{l}0.68 \\
(1.29)\end{array}$ & $\begin{array}{l}1.93 * * * \\
(3.07)\end{array}$ & $\begin{array}{l}1.04 * * * \\
(2.63)\end{array}$ & & $\begin{array}{l}0.04 * * * \\
(3.03)\end{array}$ & $\begin{array}{l}0.10 * * \\
(2.03)\end{array}$ & $\begin{array}{l}-0.02 \\
(-0.30)\end{array}$ & $\begin{array}{l}0.03 \\
(1.11)\end{array}$ & 1.39 & $\begin{array}{l}0.66 \\
(0.49)\end{array}$ \\
\hline
\end{tabular}

Notes: The table presents Fama-MacBeth (1973) cross-sectional regression results using the excess returns on 25 size- and bookto-market-sorted portfolios. The full sample factor loadings, which are used as the independent variables in the regressions, are computed in one time-series regression. Figures in smooth brackets are the respective t-statistics adjusted for heteroskedasticity and autocorrelation. *, **, and *** denotes a rejection of the null hypothesis at the $10 \%, 5 \%$, and $1 \%$ respectively. 
Table 2: Monthly factor risk premia of the 25 size- and book-to-market-sorted portfolios, July 1963 and June 2010

\begin{tabular}{|c|c|c|c|c|c|c|}
\hline \multicolumn{7}{|c|}{ Market risk premium } \\
\hline & Growth & BM2 & BM3 & BM4 & Value & Average \\
\hline Small & 0.56 & 0.48 & 0.43 & 0.39 & 0.42 & 0.46 \\
\hline Size 2 & 0.54 & 0.46 & 0.41 & 0.39 & 0.43 & 0.45 \\
\hline Size 3 & 0.51 & 0.44 & 0.39 & 0.36 & 0.40 & 0.42 \\
\hline Size 4 & 0.47 & 0.42 & 0.40 & 0.37 & 0.40 & 0.41 \\
\hline Big & 0.38 & 0.36 & 0.34 & 0.32 & 0.34 & 0.35 \\
\hline Average & 0.49 & 0.43 & 0.39 & 0.37 & 0.40 & 0.42 \\
\hline \multicolumn{7}{|c|}{$\underline{\text { Ex-ante volatility risk premium }}$} \\
\hline & Growth & BM2 & BM3 & BM4 & Value & Average \\
\hline Small & 0.20 & 0.26 & 0.33 & 0.29 & 0.35 & 0.29 \\
\hline Size 2 & 0.17 & 0.35 & 0.24 & 0.18 & 0.26 & 0.24 \\
\hline Size 3 & 0.07 & 0.18 & 0.20 & 0.20 & 0.29 & 0.19 \\
\hline Size 4 & 0.02 & 0.09 & 0.15 & 0.24 & 0.28 & 0.15 \\
\hline Big & -0.09 & 0.06 & 0.09 & 0.06 & -0.11 & 0.00 \\
\hline Average & 0.07 & 0.18 & 0.20 & 0.20 & 0.21 & 0.17 \\
\hline
\end{tabular}


Table 3: Cross-sectional regressions using ex-ante volatility in up and down market: Sample period is between July 1963 and June 2010

\begin{tabular}{|c|c|c|c|c|c|c|c|c|c|c|c|c|}
\hline Model & $\begin{array}{l}\gamma_{0} \\
\operatorname{Int}\end{array}$ & $\begin{array}{l}\gamma_{1} \\
E P M\end{array}$ & $\begin{array}{l}\gamma_{2} \\
S M B\end{array}$ & $\begin{array}{l}\gamma_{3} \\
H M L\end{array}$ & $\begin{array}{l}\gamma_{4} \\
E A V^{u p}\end{array}$ & $\begin{array}{l}\gamma_{5} \\
E A V^{\text {down }}\end{array}$ & $\begin{array}{l}\gamma_{6} \\
{ }^{n} E A M\end{array}$ & $\begin{array}{l}\gamma_{7} \\
D E F\end{array}$ & $\begin{array}{l}\gamma_{8} \\
T E R M\end{array}$ & $\begin{array}{l}\gamma_{9} \\
R F\end{array}$ & $\begin{array}{l}\gamma_{10} \\
D I V\end{array}$ & $R^{2}\left(\bar{R}^{2}\right)$ \\
\hline 1 & $\begin{array}{l}0.54 * * * \\
(2.57)\end{array}$ & & & & $\begin{array}{l}0.31 \\
(1.54)\end{array}$ & $\begin{array}{l}1.33^{* * *} \\
(5.15)\end{array}$ & & & & & & $\begin{array}{l}0.12 \\
(0.08)\end{array}$ \\
\hline 2 & $\begin{array}{l}0.79 * * \\
(2.01)\end{array}$ & $\begin{array}{l}-0.32 \\
(-0.74)\end{array}$ & & & $\begin{array}{l}1.06 * * * \\
(2.87)\end{array}$ & $\begin{array}{l}1.13^{* * *} \\
(3.01)\end{array}$ & & & & & & $\begin{array}{l}0.40 \\
(0.34)\end{array}$ \\
\hline 3 & $\begin{array}{l}0.13 \\
(0.36)\end{array}$ & $\begin{array}{l}-0.41 \\
(-0.97)\end{array}$ & $\begin{array}{l}0.76 \\
(1.51)\end{array}$ & $\begin{array}{l}2.39 * * * \\
(5.35)\end{array}$ & $\begin{array}{l}0.42 * * \\
(2.01)\end{array}$ & $\begin{array}{l}0.54^{* * *} \\
(2.60)\end{array}$ & & & & & & $\begin{array}{l}0.51 \\
(0.42)\end{array}$ \\
\hline 4 & $\begin{array}{l}0.46^{* *} \\
(2.43)\end{array}$ & & & & $\begin{array}{l}0.81 \text { *** } \\
(2.96)\end{array}$ & $\begin{array}{l}0.63^{* *} \\
(2.16)\end{array}$ & $\begin{array}{l}0.10 \\
(0.85)\end{array}$ & & & & & $\begin{array}{l}0.37 \\
(0.31)\end{array}$ \\
\hline 5 & $\begin{array}{l}0.63 * * * \\
(3.51)\end{array}$ & & $\begin{array}{l}0.68 \\
(1.54)\end{array}$ & $\begin{array}{l}1.65 * * * \\
(2.57)\end{array}$ & $\begin{array}{l}1.06 * * * \\
(4.51)\end{array}$ & $\begin{array}{l}-0.11 \\
(-0.39)\end{array}$ & $\begin{array}{l}0.20 \\
(1.07)\end{array}$ & & & & & $\begin{array}{l}0.46 \\
(0.36)\end{array}$ \\
\hline 6 & $\begin{array}{l}0.30 \\
(1.49)\end{array}$ & & & & $\begin{array}{l}0.04 \\
(0.30)\end{array}$ & $\begin{array}{l}1.79 * * * \\
(5.49)\end{array}$ & & $\begin{array}{l}0.03 * * * \\
(2.73)\end{array}$ & $\begin{array}{l}0.15^{* * *} \\
(4.12)\end{array}$ & $\begin{array}{l}-0.02 \\
(-0.25)\end{array}$ & $\begin{array}{l}0.01 \\
(0.22)\end{array}$ & $\begin{array}{l}0.47 \\
(0.34)\end{array}$ \\
\hline 7 & $\begin{array}{l}0.86 * * * \\
(2.60)\end{array}$ & $\begin{array}{l}-0.32 \\
(-0.86)\end{array}$ & $\begin{array}{l}0.68 \\
(1.29)\end{array}$ & $\begin{array}{l}1.93 * * * \\
(3.07)\end{array}$ & $\begin{array}{l}0.31 * \\
(1.93)\end{array}$ & $\begin{array}{l}0.73^{* *} \\
(2.92)\end{array}$ & & $\begin{array}{l}0.04 * * * \\
(3.03)\end{array}$ & $\begin{array}{l}0.10^{* *} \\
(2.03)\end{array}$ & $\begin{array}{l}-0.02 \\
(-0.30)\end{array}$ & $\begin{array}{l}0.03 \\
(1.11)\end{array}$ & $\begin{array}{l}0.66 \\
(0.49)\end{array}$ \\
\hline
\end{tabular}

Notes: The first row of the table presents the second-stage cross-sectional regressions including the intercepts and slopes in percent per month. We use dummies $\delta$ to define up and down market by $E A V^{u p}=\delta * E A V$ and $E A V^{\text {down }}=(1-\delta) * E A V$. For model 1-3, 6, and 7, we define $\delta=1$ if $E P M_{t}>\operatorname{Average}(E P M)$, and $\delta=0$ if $E P M_{t} \leq \operatorname{Average}(E P M)$. For model 4 and 5, we define $\delta=1$ if $E A M_{t} \leq$ Average $(E A M)$, and $\delta=0$ if $E A M_{t}>$ Average $(E A M)$. Figures in smooth brackets are the respective tstatistics adjusted for heteroskedasticity and autocorrelation. *,**, and *** denotes a rejection of the null hypothesis at the $10 \%$, $5 \%$, and $1 \%$ respectively. 


\section{Appendix}

In this appendix we provide three sets of robustness results, as discussed in subsection 4.2, for the Fama-MacBeth (1973) cross-sectional regression (FM-CSR). They include a sub-period analysis, an estimation of CSRs with zero intercept, and an inclusion of various common risk factors as well as firm characteristics.

Table A1 re-evaluates the FM-CSR results using the 25 size- and book-to-market-sorted portfolios for four different sample periods: July 1970-June 2010, July 1970-June 2010, July 1970-June 2010, and July 2000-June 2010. The risk premium of the $E A V$ factor is both positive and statistically significant for all four sub-periods. For example, the time-varying volatility commands positive risk premia that range from 1.03\% to 1.71\% over the July 1970-June 2010 period, and $0.83 \%$ to $1.99 \%$ over the July 1980 -June 2010 period. As documented in our reported results, a specification with Fama-French factors and the $E A V$ factor (i.e., model 3) consistently does a better job in explaining the cross-section of portfolio returns than any other specification.

Table A2 replicates the FM-CSR by excluding the intercept. The results suggest that omitting the intercept produces a slightly higher benchmark $E A V$ risk premium of $2.45 \%$ for the restricted model. When the Fama-French risk factors are introduced as additional variables in the CSR, they depress the magnitude of the slope coefficient of $E A V$ to $0.88 \%$, but it remains statistically significant at the $1 \%$ level. The estimated risk premium for $S M B$ and $H M L$ factors shows very little change with the zero intercept restriction in the cross-section. In contrast, the estimated risk premium for the aggregate stock market, both ex-post and ex-ante, changes substantially. When used in the presence of the $E A V$, the estimated risk premium for $E P M$ rises to $0.39 \%$ per month from $-0.32 \%$ per month. Similarly, the monthly estimated risk premium for $E A M$ increases $^{20}$ from $0.10 \%$ to $1.02 \%$. The $E A V$ risk factor obtains a stable positive premium when matched up against the $E A M$ risk premium or macroeconomic conditioning variables. The premium on $D E F$ and TERM remains robust in the presence of Fama-French risk factors, thereby indicating that

\footnotetext{
${ }^{20}$ This result is consistent with our earlier observation that the factor betas have little variation across the 25 portfolios, causing a multicollienarity problem and a large positive intercept term (Jagannathan and Wang (2007), Savov (2011)).
} 
dividend yields and term premium are valid determinants of the cross-section of stock returns even in the presence of size and value factors.

In Table A3, we first include two firm-level characteristics such as logarithm of firm size and $B E / M E$ ratio, and additional common risk factors such as momentum, and investigate whether they have any significant influence on the role of $E A V$ in the CSR. When the momentum factor is included in the CSR (model 1), both EPM and EAV coefficients show small marginal change. The same result remains visible when several lags of EPV measure (model 9-10) are annexed in the CSR. The slope coefficient of the lagged value of $E A V$ is not significant (not reported) and its presence has no economic significance on the slopes of the contemporaneous value of EPM and $E A V$. Therefore, the explanatory power of $E A V$ persists even after accounting for the risk embodied in momentum, firm characteristics, and $E P V$. Information from both past portfolio and market returns improves the performance of $E A V$ measure. We also utilize two rolling regression estimation method - the reverse recursive window (model 7) and the five-year rolling window (model 8), and both generates slightly different slope coefficients for $E P M$ and $E A V$ risk factors, but remain consistent with our previous findings ${ }^{21}$. Finally, since the betas are generated regressors, following Shanken and Zhou (2007) we adjust the standard errors of $\gamma$ terms. As shown in model (12), even in the presence of modified standard error estimate, the $E A V$ beta remains highly significant.

\footnotetext{
${ }^{21}$ In the reverse recursive window estimates, we keep the ending date as fixed, and the window size becomes smaller, as the starting date is advanced.
} 
Table A1: Cross-sectional regressions using ex-ante volatility for various sub-periods

\begin{tabular}{|c|c|c|c|c|c|c|c|c|}
\hline Model & $\begin{array}{l}\gamma_{0} \\
\text { Intercept }\end{array}$ & $\begin{array}{l}\gamma_{1} \\
E P M\end{array}$ & $\begin{array}{l}\gamma_{2} \\
S M B\end{array}$ & $\begin{array}{l}\gamma_{3} \\
H M L\end{array}$ & $\begin{array}{l}\gamma_{4} \\
E A V\end{array}$ & $\begin{array}{l}\gamma_{5} \\
E A M\end{array}$ & $R M S E$ & $R^{2}\left(\bar{R}^{2}\right)$ \\
\hline \multicolumn{9}{|c|}{ Sample period: July1970 - June 2010} \\
\hline 1 & $\begin{array}{l}0.49 * * \\
(2.14)\end{array}$ & & & & $\begin{array}{l}1.47^{* * * *} \\
(3.72)\end{array}$ & & 2.10 & $0.14(0.10)$ \\
\hline 2 & $\begin{array}{l}1.12^{* * *} \\
(2.57)\end{array}$ & $\begin{array}{l}-0.65 \\
(-1.37)\end{array}$ & & & $\begin{array}{l}1.71^{* * *} \\
(3.34)\end{array}$ & & 1.64 & $0.40(0.35)$ \\
\hline 3 & $\begin{array}{l}0.39 \\
(0.99)\end{array}$ & $\begin{array}{l}0.12 \\
(0.26)\end{array}$ & $\begin{array}{l}0.45 \\
(0.85)\end{array}$ & $\begin{array}{l}2.32 * * * \\
(4.99)\end{array}$ & $\begin{array}{l}1.03^{* *} \\
(2.38)\end{array}$ & & 1.54 & $0.51(0.42)$ \\
\hline 4 & $\begin{array}{l}0.57 * * * \\
(2.69)\end{array}$ & & & & $\begin{array}{l}1.66^{* * * *} \\
(3.16)\end{array}$ & $\begin{array}{l}0.04 \\
(0.35)\end{array}$ & 1.67 & $0.39(0.33)$ \\
\hline 5 & $\begin{array}{l}0.67 * * * \\
(3.27)\end{array}$ & & $\begin{array}{l}0.17 \\
(0.37)\end{array}$ & $\begin{array}{l}1.72 * * \\
(2.40)\end{array}$ & $\begin{array}{l}1.08 * * * \\
(2.57)\end{array}$ & $\begin{array}{l}0.03 \\
(0.16)\end{array}$ & 1.61 & $0.49(0.38)$ \\
\hline \multicolumn{9}{|c|}{ Sample period: July 1980 - June 2010} \\
\hline 1 & $\begin{array}{l}0.66 * * * \\
(2.58)\end{array}$ & & & & $\begin{array}{l}0.66^{* * *} \\
(2.87)\end{array}$ & & 2.14 & $0.11(0.07)$ \\
\hline 2 & $\begin{array}{l}1.36^{* *} \\
(2.49)\end{array}$ & $\begin{array}{l}-0.75 \\
(-1.31)\end{array}$ & & & $\begin{array}{l}0.88 * * * \\
(2.61)\end{array}$ & & 1.66 & $0.40(0.35)$ \\
\hline 3 & $\begin{array}{l}0.68 \\
(1.53)\end{array}$ & $\begin{array}{l}-0.09 \\
(-0.19)\end{array}$ & $\begin{array}{l}0.22 \\
(0.52)\end{array}$ & $\begin{array}{l}1.75^{* *} \\
(3.10)\end{array}$ & $\begin{array}{l}0.88 * * \\
(2.55)\end{array}$ & & 1.56 & $0.51(0.41)$ \\
\hline 4 & $\begin{array}{l}0.75^{* * *} \\
(3.19)\end{array}$ & & & & $\begin{array}{l}0.81 * * * \\
(3.34)\end{array}$ & $\begin{array}{l}0.47 \\
(1.26)\end{array}$ & 1.90 & $0.28(0.21)$ \\
\hline 5 & $\begin{array}{l}0.84 * * \\
(2.47)\end{array}$ & & $\begin{array}{l}0.27 \\
(0.64)\end{array}$ & $\begin{array}{l}1.70^{* *} \\
(2.34)\end{array}$ & $\begin{array}{l}0.52 * * \\
(2.49)\end{array}$ & $\begin{array}{l}0.15 \\
(0.63)\end{array}$ & 1.64 & $0.47(0.36)$ \\
\hline
\end{tabular}

Sample period: July 1990 - June 2010

\begin{tabular}{|c|c|c|c|c|c|c|c|c|}
\hline 1 & $\begin{array}{l}0.63 * * \\
(2.05)\end{array}$ & & & & $\begin{array}{l}0.71 * * * \\
(2.66)\end{array}$ & & 2.16 & $0.10(0.06)$ \\
\hline 2 & $\begin{array}{l}0.93 \\
(1.38)\end{array}$ & $\begin{array}{l}-0.39 \\
(-0.52)\end{array}$ & & & $\begin{array}{l}1.09 * * * \\
(2.72)\end{array}$ & & 1.77 & $0.38(0.32)$ \\
\hline 3 & $\begin{array}{l}0.68 \\
(1.53)\end{array}$ & $\begin{array}{l}-0.09 \\
(0.19)\end{array}$ & $\begin{array}{l}0.22 \\
(0.52)\end{array}$ & $\begin{array}{l}1.75^{* * *} \\
(3.10)\end{array}$ & $\begin{array}{l}0.87 * * * \\
(2.65)\end{array}$ & & 1.56 & $0.51(0.41)$ \\
\hline 4 & $\begin{array}{l}0.64 * * \\
(2.27)\end{array}$ & & & & $\begin{array}{l}0.76^{* *} \\
(2.41)\end{array}$ & $\begin{array}{l}0.10 \\
(0.20)\end{array}$ & 2.01 & $0.22(0.15)$ \\
\hline 5 & $\begin{array}{l}0.43^{* *} \\
(2.09)\end{array}$ & & $\begin{array}{l}0.23 \\
(0.60)\end{array}$ & $\begin{array}{l}1.36^{* *} \\
(2.02)\end{array}$ & $\begin{array}{l}0.57 * * \\
(2.09)\end{array}$ & $\begin{array}{l}0.21 \\
(0.70)\end{array}$ & 1.79 & $0.43(0.32)$ \\
\hline
\end{tabular}

Sample period: July 2000 - June 2010

\begin{tabular}{|c|c|}
\hline 1 & $\begin{array}{l}0.48 \\
(1.03)\end{array}$ \\
\hline 2 & $\begin{array}{l}0.56 \\
(1.17)\end{array}$ \\
\hline 3 & $\begin{array}{l}0.09 \\
(1.10)\end{array}$ \\
\hline 4 & $\begin{array}{l}0.35 \\
(0.96)\end{array}$ \\
\hline 5 & $\begin{array}{l}0.27 \\
(1.25)\end{array}$ \\
\hline
\end{tabular}

\begin{tabular}{|c|c|c|c|c|c|c|}
\hline \multirow{3}{*}{$\begin{array}{l}-0.43 \\
(-0.41)\end{array}$} & & & \multicolumn{2}{|l|}{$0.83 * * *$} & 2.43 & $0.11(0.07)$ \\
\hline & & & $1.99 * * *$ & & 1.95 & $0.35(0.29)$ \\
\hline & & & (2.95) & & & \\
\hline \multirow{4}{*}{$\begin{array}{l}0.34 \\
(0.33)\end{array}$} & 0.73 & $2.16 * * *$ & $1.72 * * *$ & & 1.87 & $0.46(0.35)$ \\
\hline & (1.11) & (2.79) & (2.74) & & & \\
\hline & & & $\begin{array}{l}1.03 * * \\
(2.53)\end{array}$ & $\begin{array}{l}0.10 \\
(0.45)\end{array}$ & 2.09 & $0.22(0.15)$ \\
\hline & $\begin{array}{l}0.89 \\
(1.19)\end{array}$ & $\begin{array}{l}2.03 * * \\
(2.02)\end{array}$ & $\begin{array}{l}0.84 * * \\
(2.46)\end{array}$ & $\begin{array}{l}0.06 \\
(0.31)\end{array}$ & 2.01 & $0.38(0.26)$ \\
\hline
\end{tabular}

Notes: The table presents Fama-MacBeth (1973) cross-sectional regression results using the excess returns on 25 size- and bookto-market-sorted portfolios for various sub-periods. Figures in smooth brackets are the respective t-statistics adjusted for heteroskedasticity and autocorrelation. *, **, and *** denotes a rejection of the null hypothesis at the $10 \%$, 5\%, and $1 \%$ respectively. 
Table A2: Cross-sectional regressions without an intercept: Sample period is between July 1963 and June 2010

\begin{tabular}{|c|c|c|c|c|c|c|c|c|c|c|c|}
\hline Model & $\begin{array}{l}\gamma_{1} \\
E P M\end{array}$ & $\begin{array}{l}\gamma_{2} \\
S M B\end{array}$ & $\begin{array}{l}\gamma_{3} \\
H M L\end{array}$ & $\begin{array}{l}\gamma_{4} \\
E A V\end{array}$ & $\begin{array}{l}\gamma_{5} \\
E A M \\
\end{array}$ & $\begin{array}{l}\gamma_{6} \\
D E F\end{array}$ & $\begin{array}{l}\gamma_{7} \\
\text { TERM }\end{array}$ & $\begin{array}{l}\gamma_{8} \\
R F\end{array}$ & $\begin{array}{l}\gamma_{9} \\
D I V\end{array}$ & $R M S E$ & $R^{2}\left(\bar{R}^{2}\right)$ \\
\hline 1 & & & & $\begin{array}{l}2.45^{* * * *} \\
(3.92)\end{array}$ & & & & & & 3.77 & $\begin{array}{l}0.32 \\
(0.29)\end{array}$ \\
\hline 2 & $\begin{array}{l}0.39 * * \\
(2.42)\end{array}$ & & & $\begin{array}{l}1.84 * * * \\
(4.29)\end{array}$ & & & & & & 2.48 & $\begin{array}{l}0.61 \\
(0.58)\end{array}$ \\
\hline 3 & $\begin{array}{l}0.53 * * * \\
(2.83)\end{array}$ & $\begin{array}{l}0.85^{* *} \\
(2.01)\end{array}$ & $\begin{array}{l}2.64 * * * \\
(3.54)\end{array}$ & $\begin{array}{l}0.88 * * * \\
(2.83)\end{array}$ & & & & & & 1.62 & $\begin{array}{l}0.79 \\
(0.76)\end{array}$ \\
\hline 4 & & & & $\begin{array}{l}2.10^{* * * *} \\
(3.98)\end{array}$ & $\begin{array}{l}1.02 * * * \\
(3.61)\end{array}$ & & & & & 2.35 & $\begin{array}{l}0.66 \\
(0.62)\end{array}$ \\
\hline 5 & & $\begin{array}{l}0.99 * * \\
(2.34)\end{array}$ & $\begin{array}{l}1.81 * * * \\
(3.05)\end{array}$ & $\begin{array}{l}1.92 * * * \\
(4.21)\end{array}$ & $\begin{array}{l}0.34^{* *} \\
(2.51)\end{array}$ & & & & & 2.16 & $\begin{array}{l}0.68 \\
(0.63)\end{array}$ \\
\hline 6 & & & & $\begin{array}{l}1.93 * * * \\
(3.36)\end{array}$ & & $\begin{array}{l}0.03 * * \\
(2.37)\end{array}$ & $\begin{array}{l}0.21 * * * \\
(5.58)\end{array}$ & $\begin{array}{l}-0.03 \\
(-0.46)\end{array}$ & $\begin{array}{l}0.02 \\
(0.72)\end{array}$ & 1.76 & $\begin{array}{l}0.70 \\
(0.65)\end{array}$ \\
\hline 7 & $\begin{array}{l}0.51^{* * *} \\
(2.64)\end{array}$ & $\begin{array}{l}0.75 \\
(1.52)\end{array}$ & $\begin{array}{l}2.59 * * * \\
(3.76)\end{array}$ & $\begin{array}{l}1.29 * * * \\
(3.07)\end{array}$ & & $\begin{array}{l}0.03 * * \\
(2.23)\end{array}$ & $\begin{array}{l}0.08^{*} \\
(1.73)\end{array}$ & $\begin{array}{l}-0.02 \\
(-0.31)\end{array}$ & $\begin{array}{l}0.00 \\
(0.34)\end{array}$ & 1.42 & $\begin{array}{l}0.86 \\
(0.80)\end{array}$ \\
\hline
\end{tabular}

Notes: The table presents Fama-MacBeth (1973) cross-sectional regression results using the excess returns on 25 size- and bookto-market-sorted portfolios without an intercept. Figures in smooth brackets are the respective t-statistics adjusted for heteroskedasticity and autocorrelation. *, **, and *** denotes a rejection of the null hypothesis at the $10 \%$, $5 \%$, and $1 \%$ respectively. 
Table A3: Cross-sectional regressions using ex-ante volatility, momentum, firm characteristics, and cay: Sample period is between July 1963 and June 2010

\begin{tabular}{|c|c|c|c|c|c|c|c|c|c|c|c|c|}
\hline \multicolumn{13}{|c|}{ Models } \\
\hline & (1) & (2) & (3) & (4) & (5) & (6) & (7) & (8) & (9) & (10) & (11) & (12) \\
\hline \multirow[t]{2}{*}{$E P M$} & $0.43^{* *}$ & $0.37 * *$ & $0.33 * *$ & $0.30 * *$ & $0.42^{* *}$ & - & $0.51^{* * *}$ & $0.47 * * *$ & $0.39 * *$ & $0.41^{* *}$ & $0.40^{* *}$ & $0.39 * *$ \\
\hline & $(2.52)$ & (2.35) & $(2.27)$ & (2.19) & $(2.48)$ & - & $(2.61)$ & $(2.57)$ & $(2.41)$ & $(2.44)$ & (2.39) & $(2.29)$ \\
\hline \multirow[t]{2}{*}{$E A V$} & $0.91 * * *$ & $0.95^{* * *}$ & $0.90 * * *$ & $0.89 * * *$ & $0.92 * * *$ & $1.03^{* * *}$ & $2.30 * * *$ & $2.11^{* * *}$ & $1.88 * * *$ & $1.89 * * *$ & $1.86 * * *$ & $1.84 * * *$ \\
\hline & $(3.02)$ & (3.11) & (2.97) & (2.95) & (3.05) & (3.18) & (3.46) & $(3.20)$ & (3.04) & (3.05) & (2.99) & $(4.02)$ \\
\hline$R M S E$ & 1.59 & 1.61 & 1.60 & 1.54 & 1.55 & 1.65 & 2.44 & 2.39 & 2. 43 & 2.42 & 2.45 & 2.48 \\
\hline & 0.78 & 0.77 & 0.79 & 0.82 & 0.81 & 0.72 & 0.59 & 0.62 & 0.60 & 0.61 & 0.62 & 0.58 \\
\hline
\end{tabular}

Notes: The table presents Fama-MacBeth (1973) cross-sectional regression results using the excess returns on 25 size- and bookto-market-sorted portfolios using additional factors and characteristics.

Model (1): The independent variables are $E P M_{t}, E A V_{t}, S M B_{t}, H M L_{t}$ and $U M D_{t} ; 1963 / 07$ to 2010/06.

Model (2): The independent variables are $E P M_{t}, E A V_{t}, S M B_{t}, H M L_{t}$ and $\ln (\text { Size })_{t} ; 1963 / 07$ to 2010/06.

Model (3): The independent variables are $E P M_{t}, E A V_{t}, S M B_{t}, H M L_{t}$ and $\ln (B M)_{t} ; 1963 / 07$ to 2010/06.

Model (4): The independent variables are $E P M_{t}, E A V_{t}, S M B_{t}, H M L_{t}, \ln (\operatorname{Size})_{t}$, and $\ln (B M)_{t}$; 1963/07 to 2010/06.

Model (5): The independent variables are $E P M_{t}, E A V_{t}, \ln (\operatorname{Size})_{t}$, and $\ln (B M)_{t}$; 1963/07 to 2010/06.

Model (6): The independent variables are $E A V_{t}, \ln (\text { Size })_{t}$, and $\ln (B M)_{t} ; 1963 / 07$ to 2010/06.

Model (7): The independent variables are $E P M_{t}$ and $E A V_{t}$; reverse recursive window in the first stage regressions, $1963 / 07$ to 2010/06.

Model (8): The independent variables are $E P M_{t}$ and $E A V_{t}$; five-year rolling window in the first stage regressions, $1963 / 07$ to 2010/06.

Model (9): The independent variables are $E P M_{t}, E A V_{t}, E P V_{t}, E P V_{t-1} ; 1963 / 07$ to 2010/06.

Model (10): The independent variables are $E P M_{t}, E A V_{t}, E P V_{t}, E P V_{t-1}, E P V_{t-2} ; 1963 / 07$ to 2010/06.

Model (11): The independent variables are $E P M_{t}, E A V_{t}, E A V_{t-1}, E A V_{t-2} ; 1963 / 07$ to 2010/06.

Model (12): The independent variables are $E P M_{t}$ and $E A V_{t}$; Shanken and Zhou (2007) standard errors, 1963/07 to 2010/06.

Figures in smooth brackets are the respective t-statistics. The standard errors are adjusted for heteroskedasticity and autocorrelation. $*$, **, and $* * *$ denotes a rejection of the null hypothesis at the $10 \%, 5 \%$, and $1 \%$ respectively. 